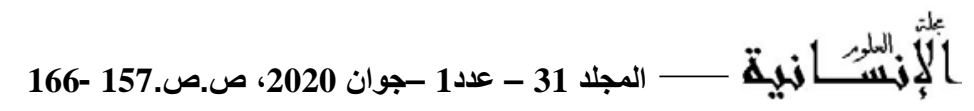

\title{
لغة الجسد في مقامات الهمذاني: المقامة القردية أنموذجا
}

Body language in the Maqamat of Hamadani : El maqama el karadia

as a model

تاريخ الاستلام : 2019/11/16 ؛ تاريخ القبول : 2020/04/04

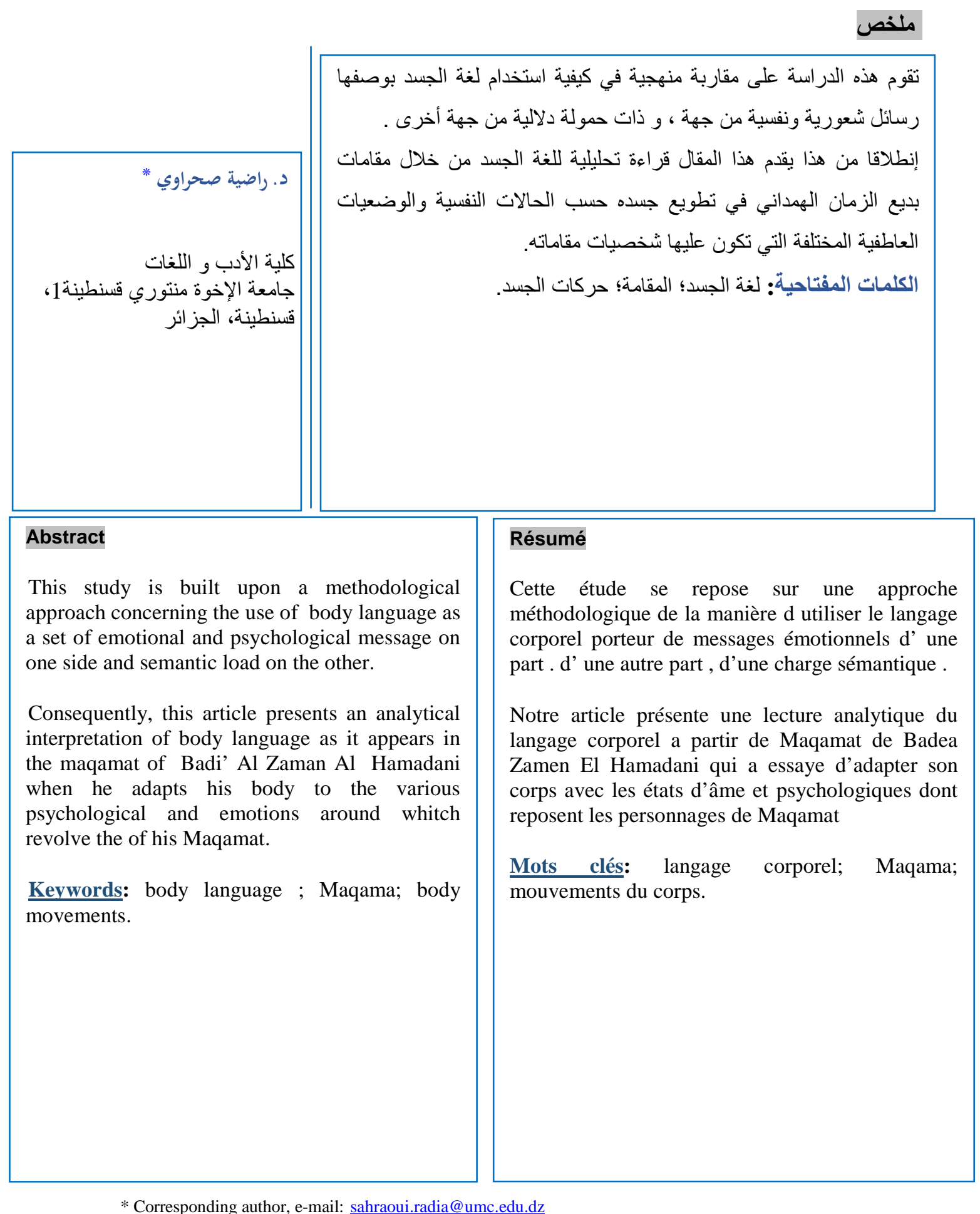

(C) جامعة الاخوة منتوري قسنطينة 1، الجزائر 2020. 
I

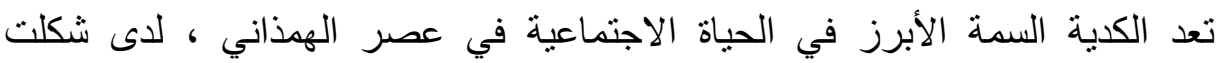
الموضوع الأساس لمقاماته ، وقد ارتبطت في أغلب المقامات بشخص فئ الأب الأسكندري

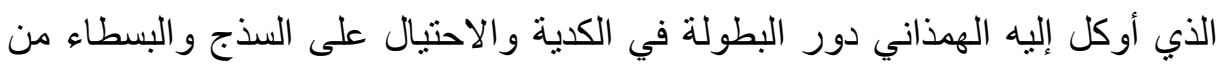

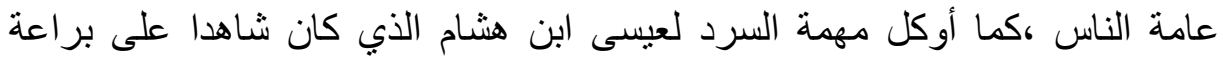

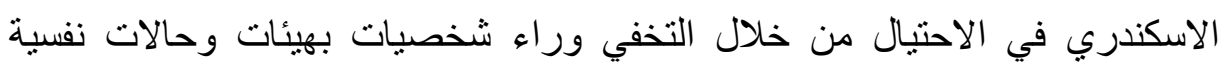

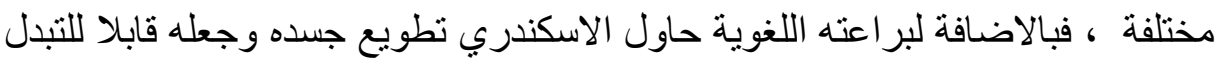

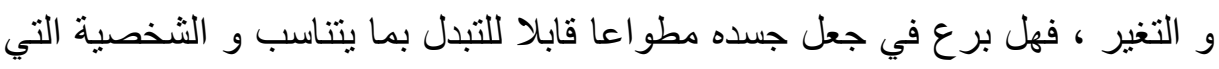

يتقصصها ؟ إن الإجابة عن هذا السؤال تحيلنا إلى دراسة لغة الجسد باعتبار ها سلوكا غير لفظي

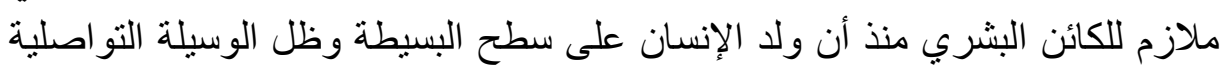

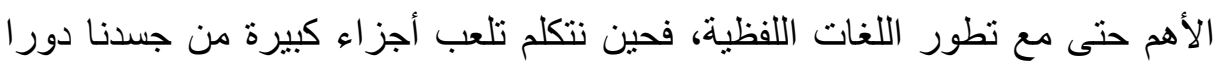

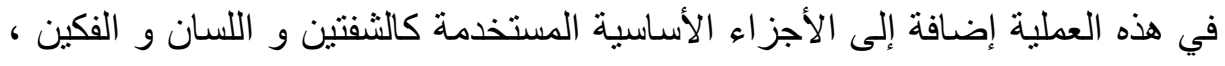

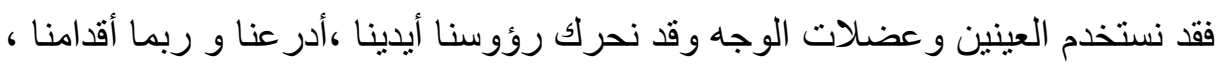
ويختلف مقدار تدخل هذه الأعضاء في عملية الكلام فيما ندعوه الإيماء المرفق بأن بالكلام

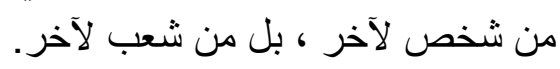

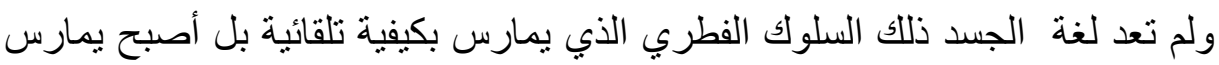

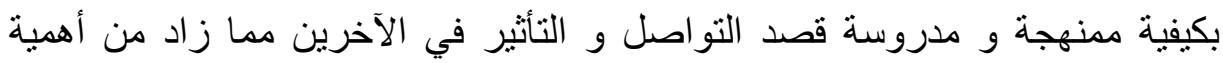

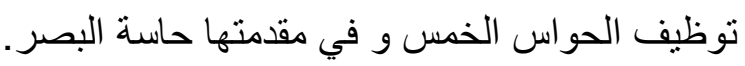

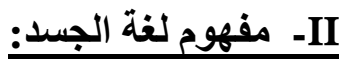

لغة الجسد هي " الإشار ات الدالة على معان بعينها بجزء من أجزاء الجسد "(1)هذه

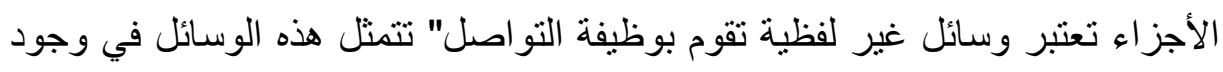

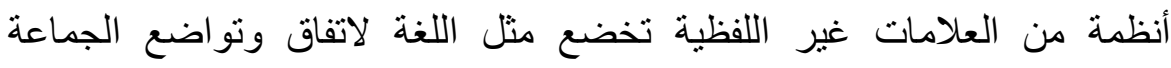
conventionality

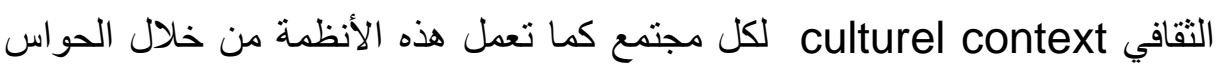

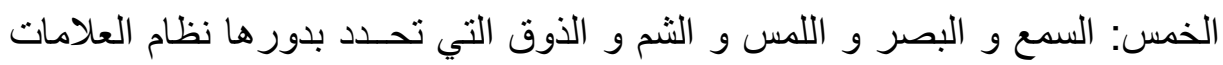

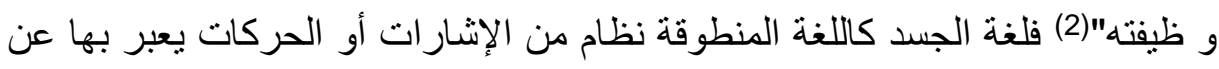

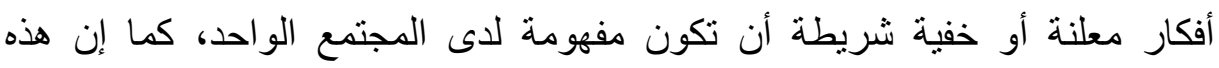

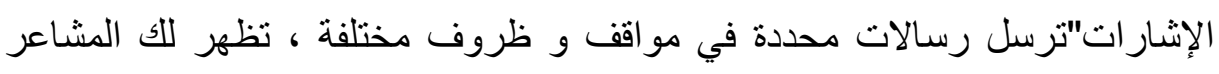

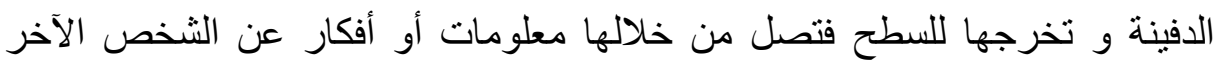

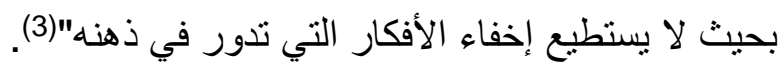

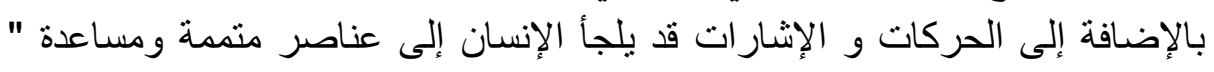
تتمثل فيما يستخدمه الإنسان من وسائط و أثياء توجد في البيئة ويستعملها الإنسان الإنسان بوصفها علامات محملة بدلالات مختلفة إلى جانب استخدامها في أغراض اض أخرى مثل 
الملابس المصنوعة الإمكانات المتاحة في البيئة مثل القطن والصوف و الحرير و الكتان التي يرتديها الإنسان بغرض الإنغات تغطية جسمه و حمايته من الحر و البرد ،و تمثل فئل

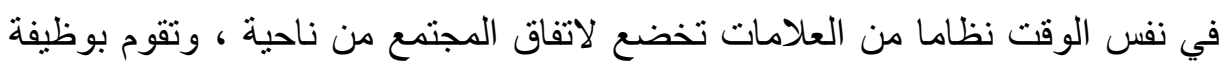

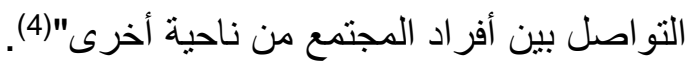

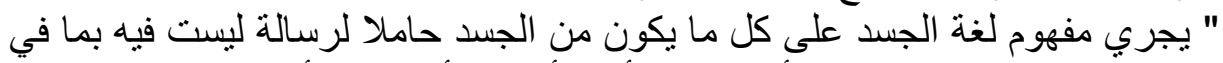

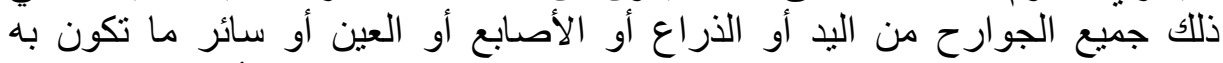

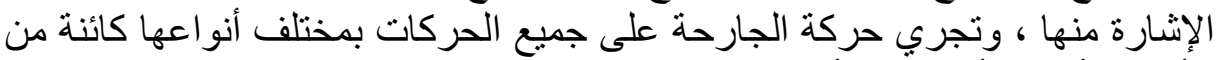

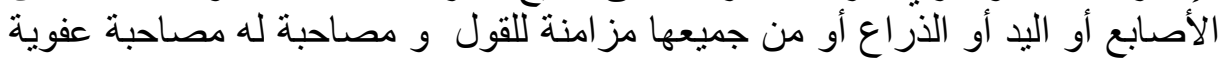

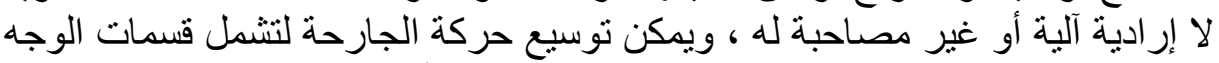

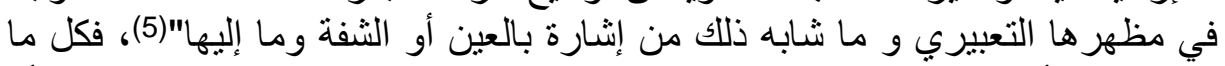

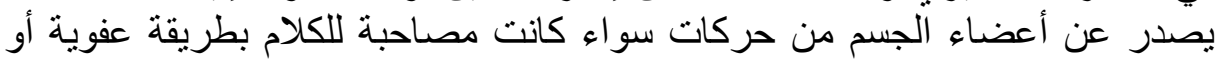

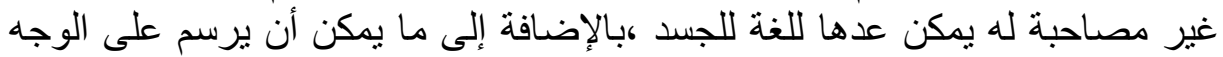

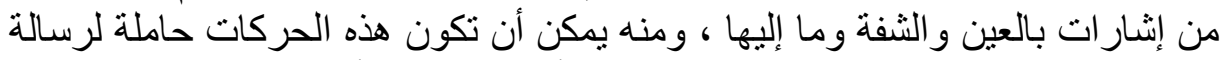

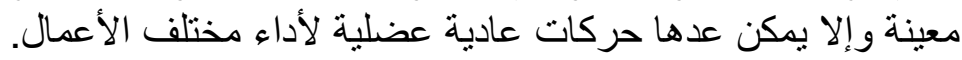

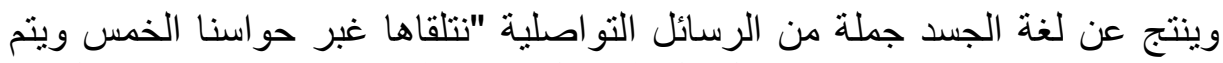

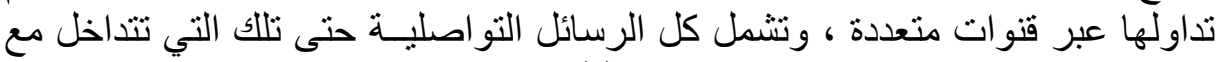

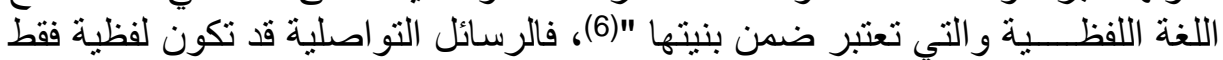

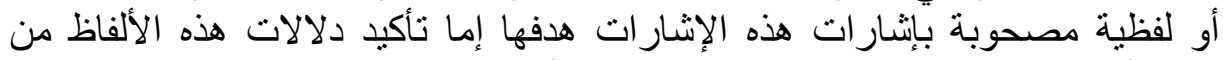

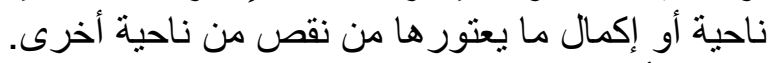

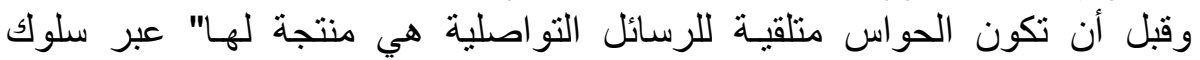

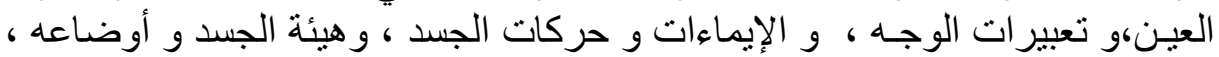

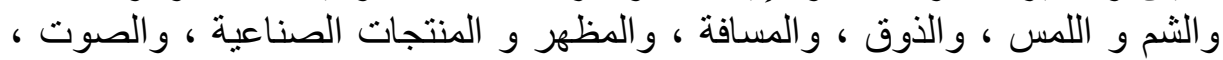

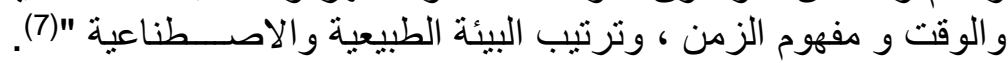

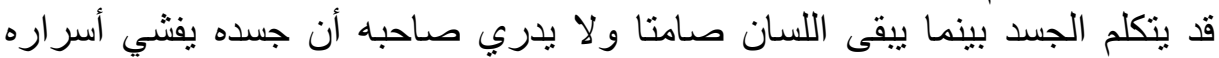

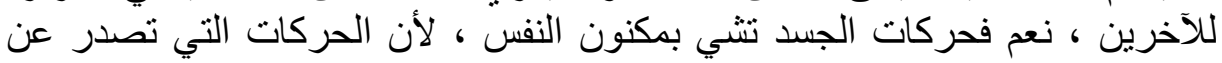

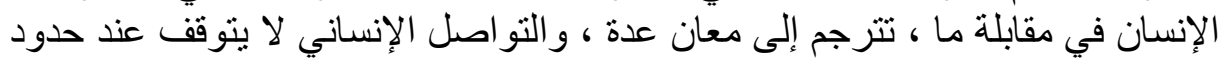

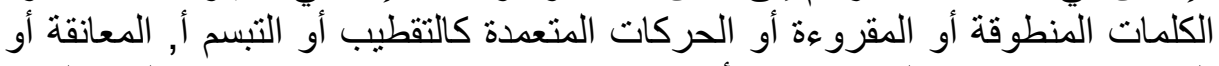

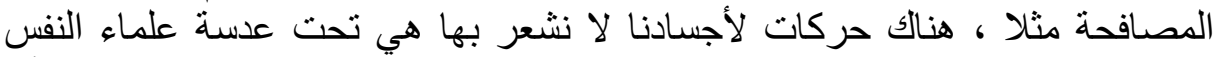

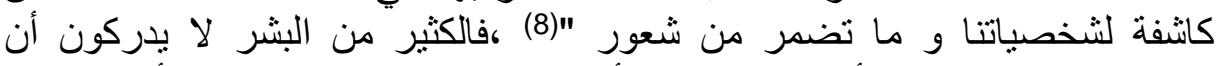

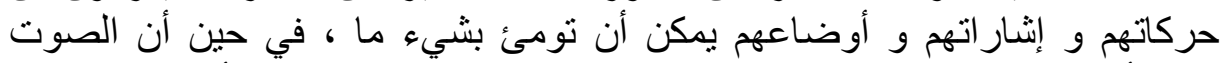

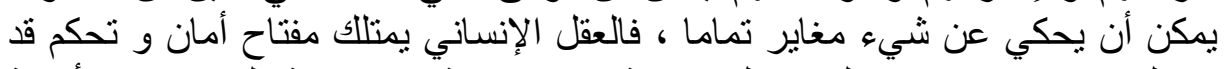

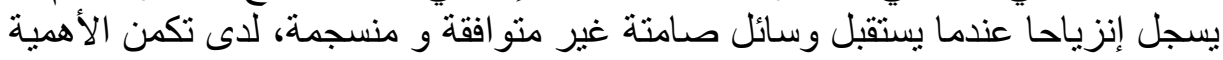

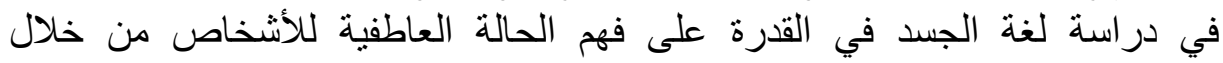
حركاتهم.

من خلال ما سبق يمكن القول أن لغة الجسد هي رسائل شعورية تنطلق من جسد الإند

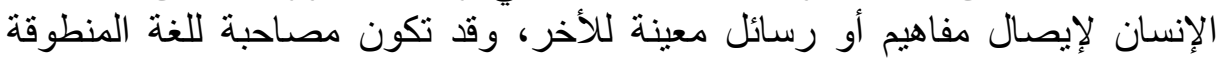
فتقوم بتأكيد دلالات هذه الألفاظ من ناحية ، أو إكمال ما يعتور ها من نقص من من ناحية 
تعتبر حركة الجسد خاصية بشرية من حيث طبيعتها و توظيفها فبالإضافة إلى في توكي

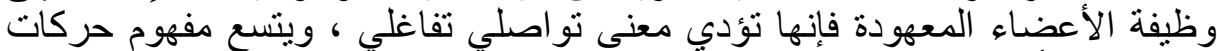

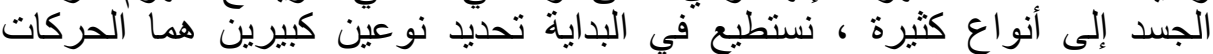

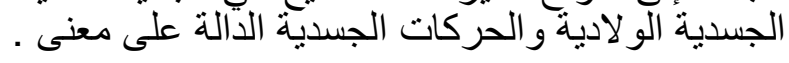

هركات جسة الحركات ولادية:

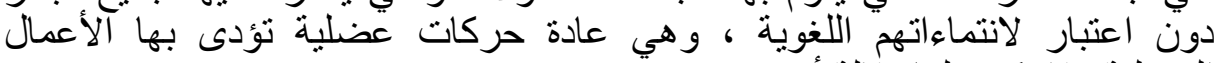

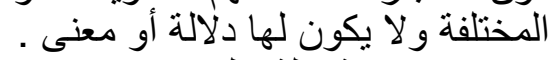

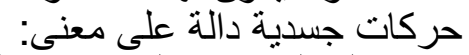

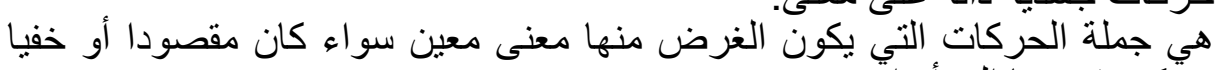

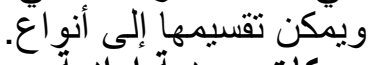

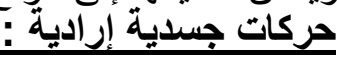

هي حركات جسدية مقصدودة يستعين بها الإنسان على آداء مر اده و تجليته و نذكر

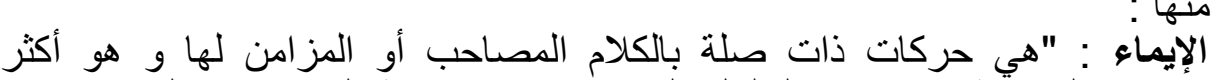

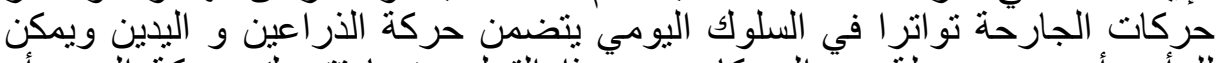

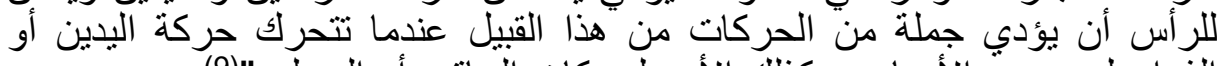

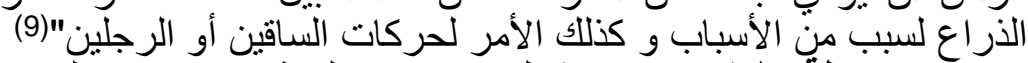

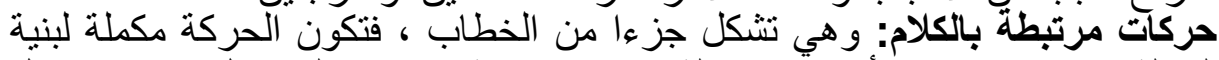

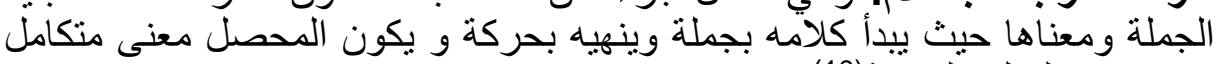

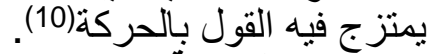

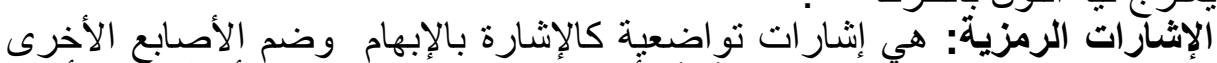

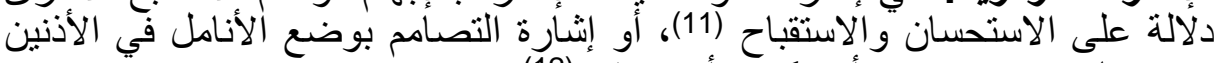

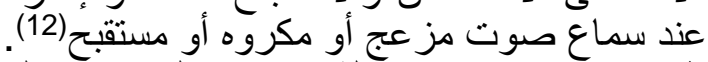

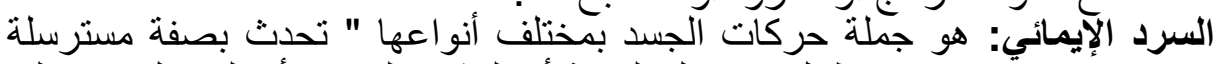

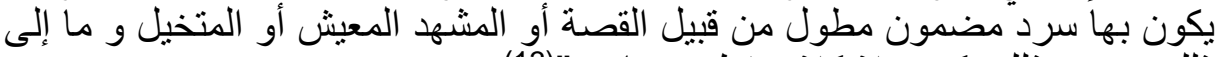

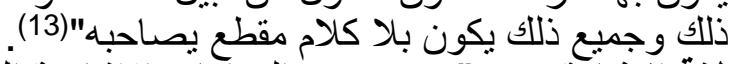

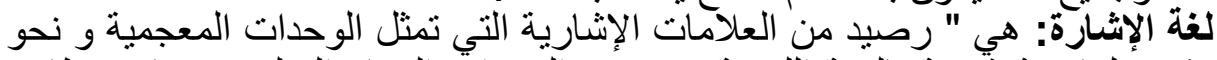

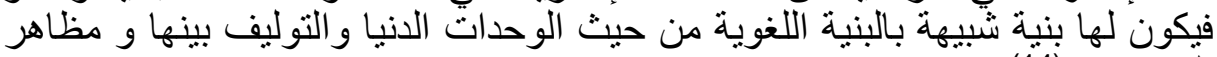

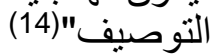
حركات جسدية تلقائية لا إرادية:

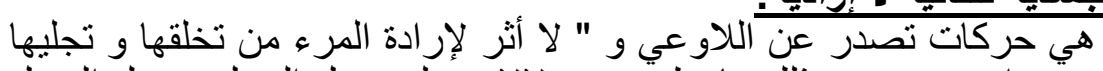

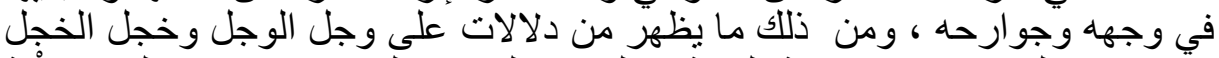

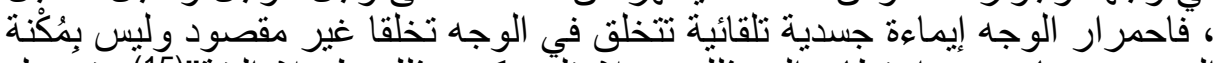

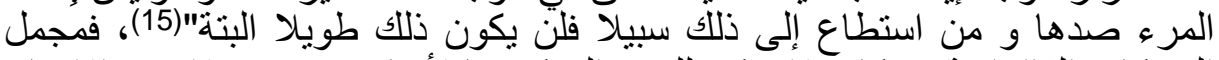

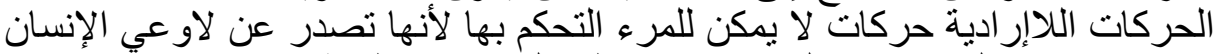

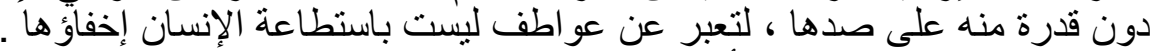

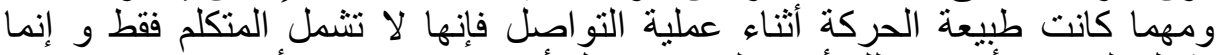

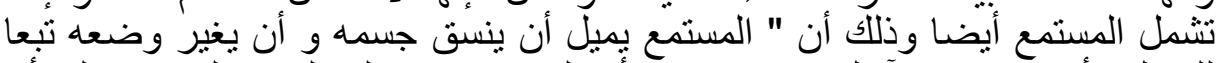

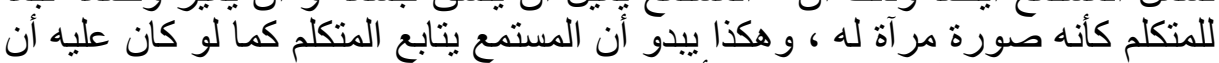

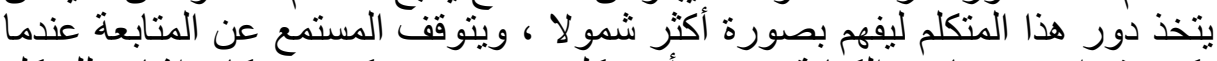

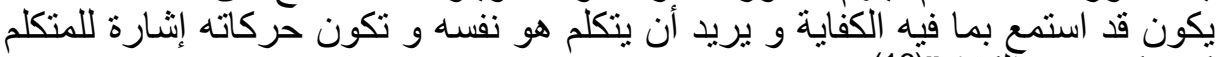
كي يكف عن ألكلام"(16) 


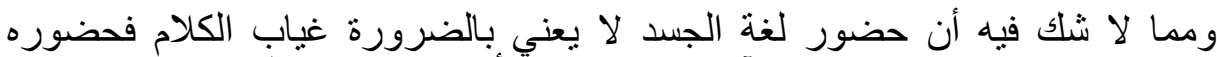

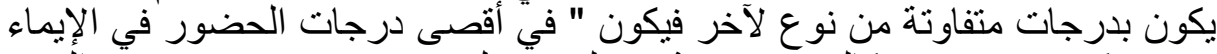

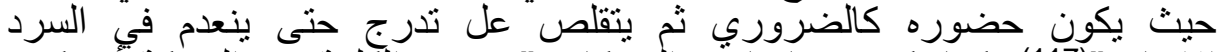

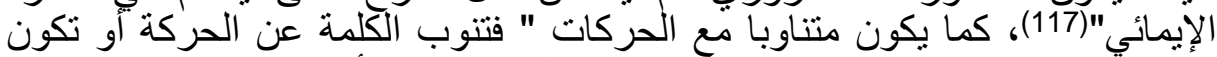

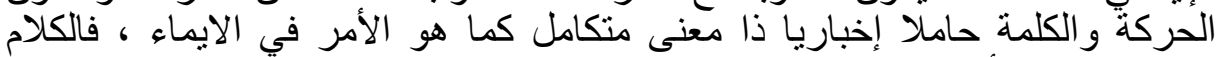

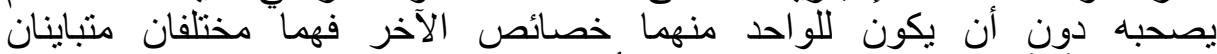

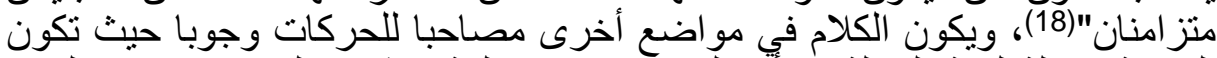

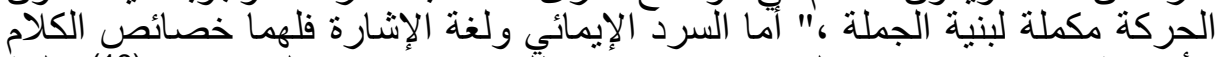

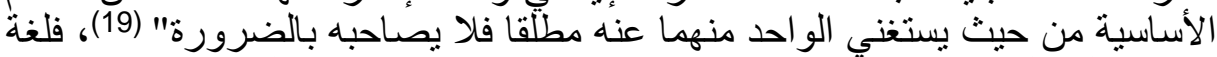

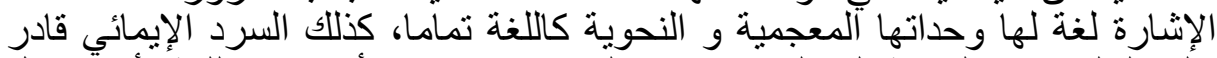

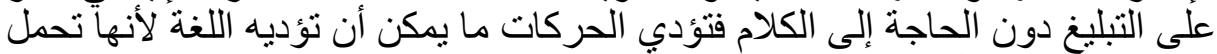

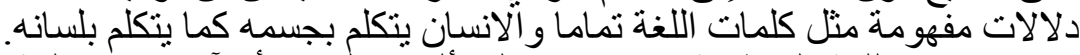

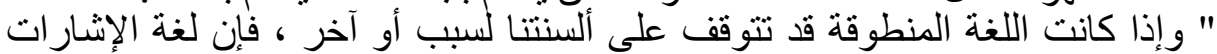

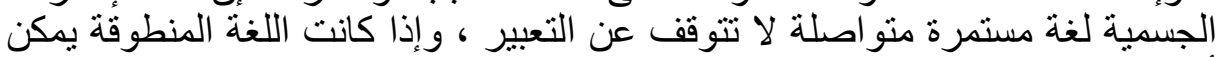

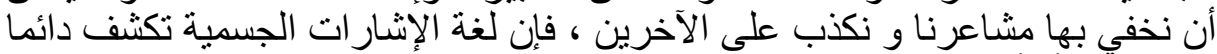

عما تخفيه" (20)

\section{IV}

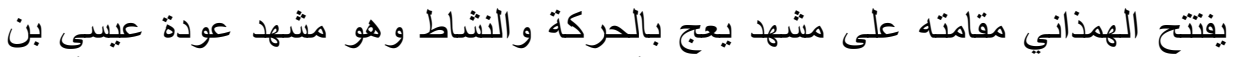

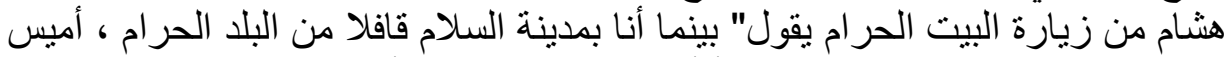

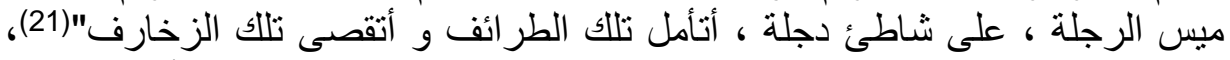

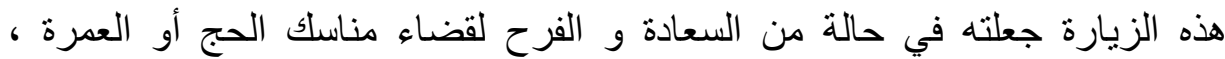

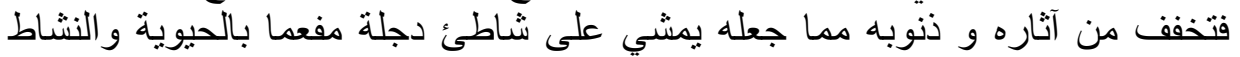

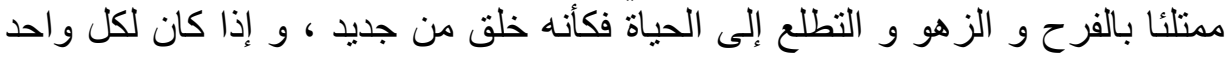

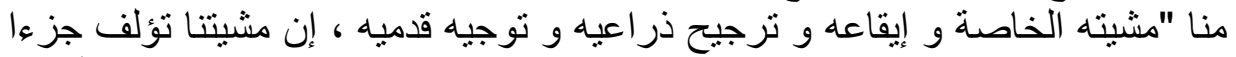

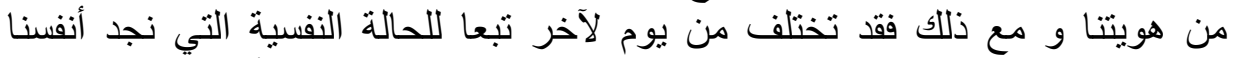

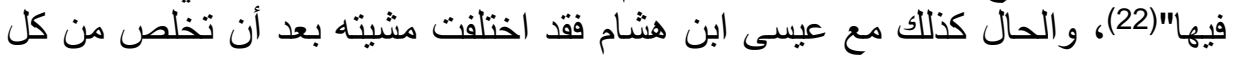

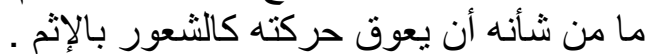

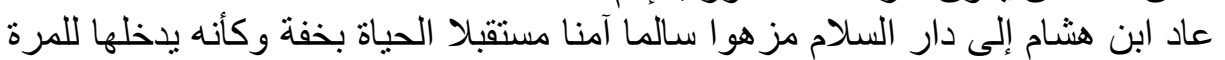

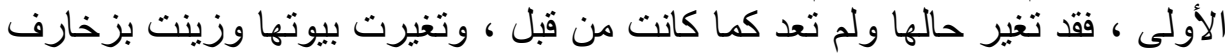

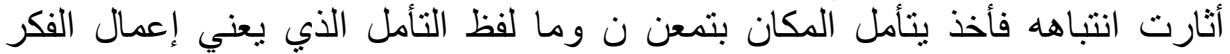

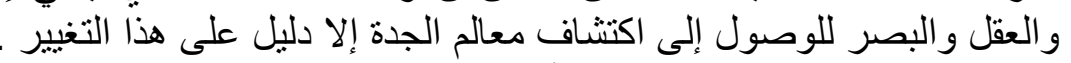

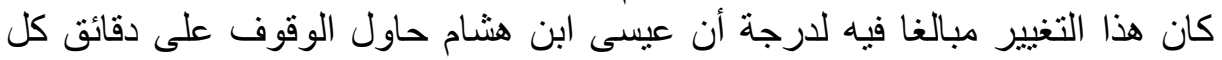

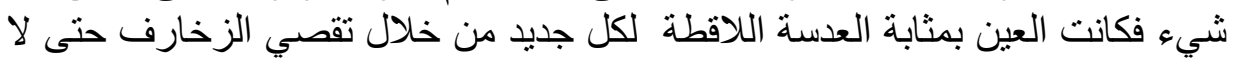

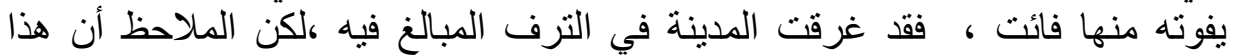

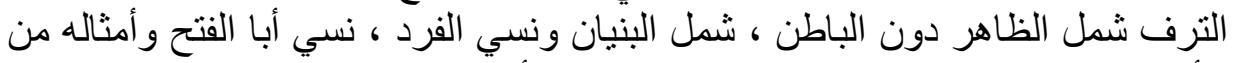

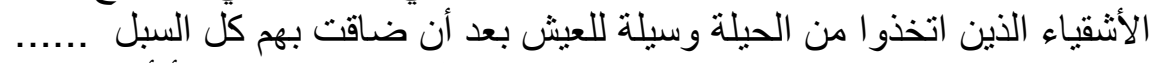

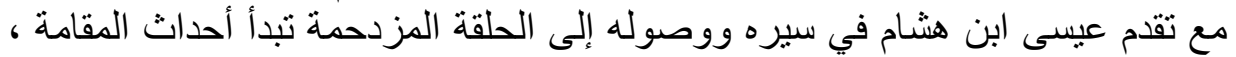

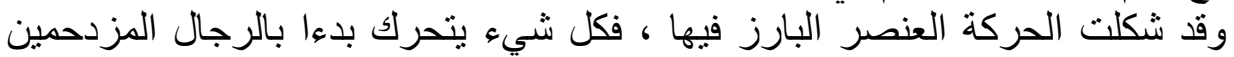

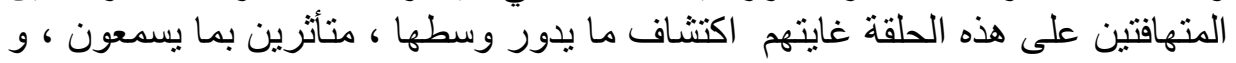

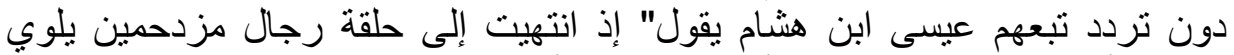

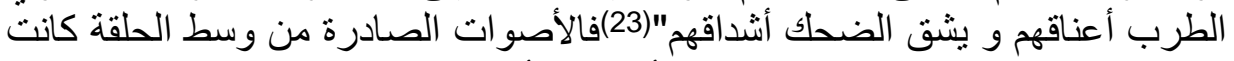

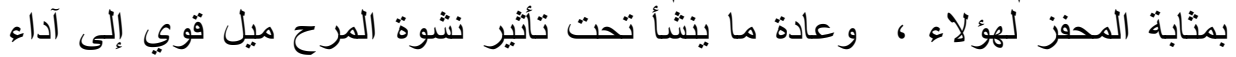

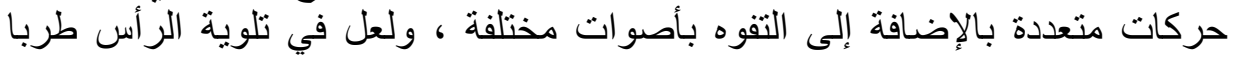

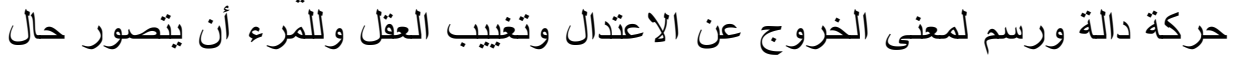




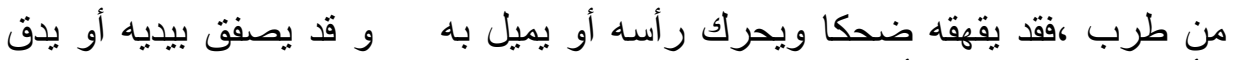

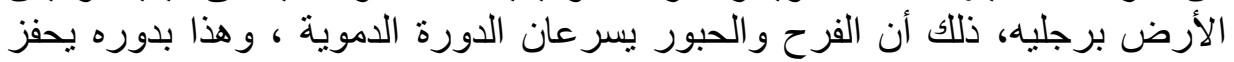

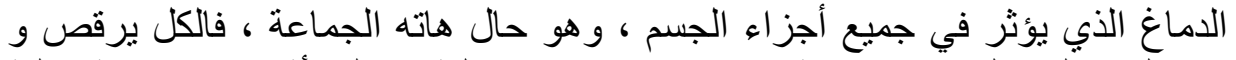

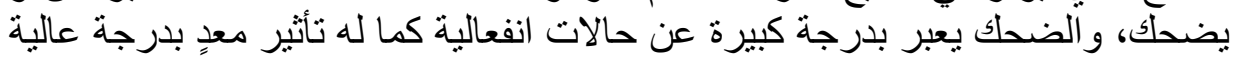

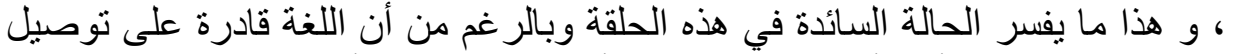

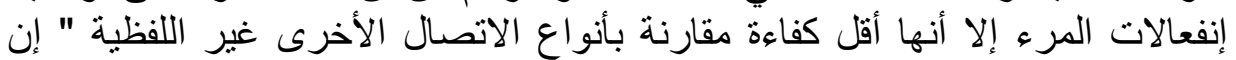

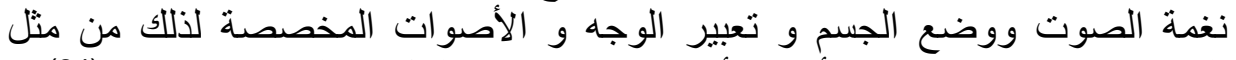

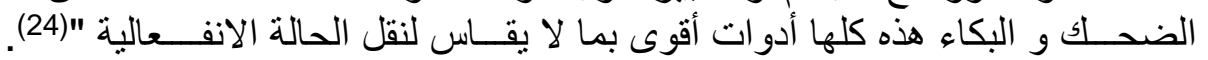

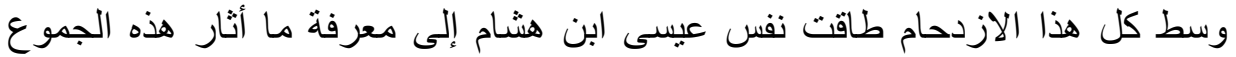

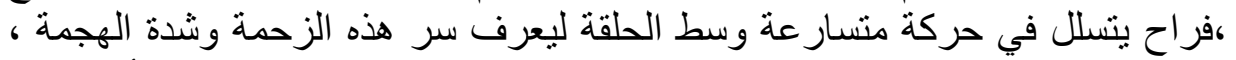

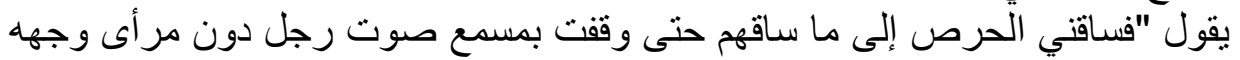

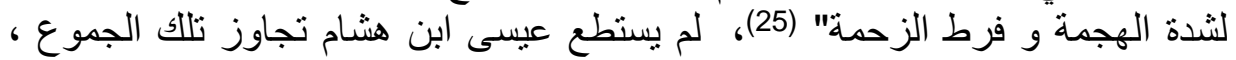

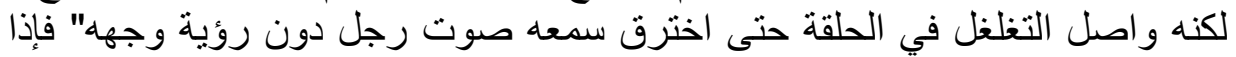

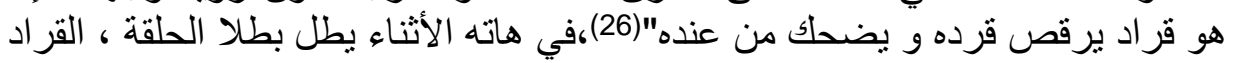

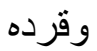

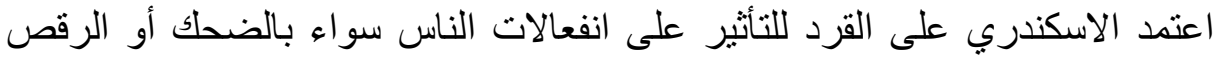

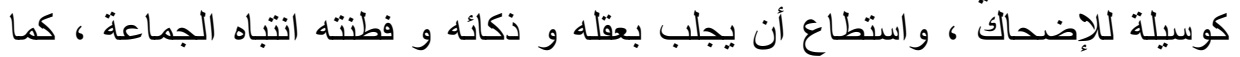

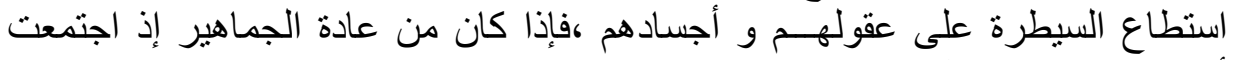

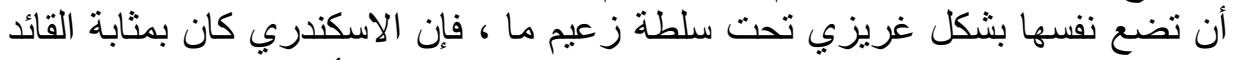

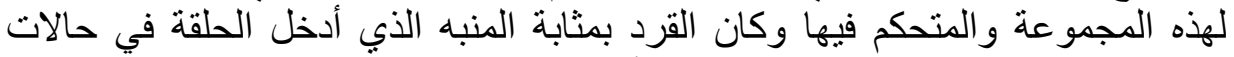

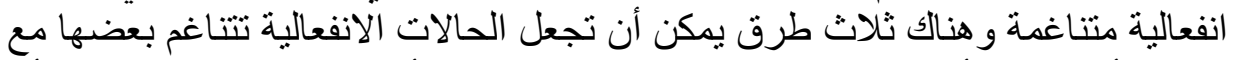

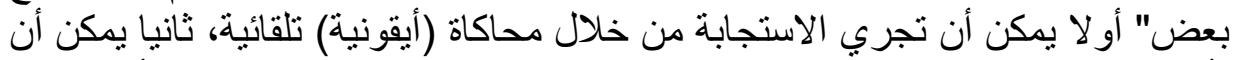

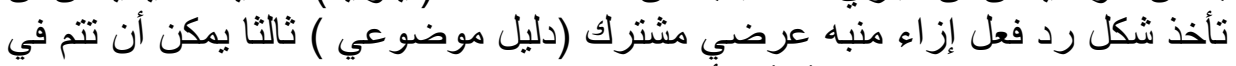

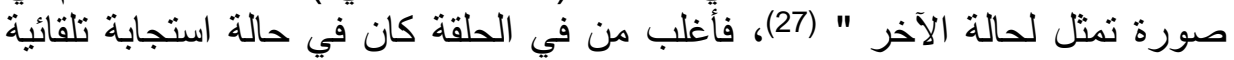

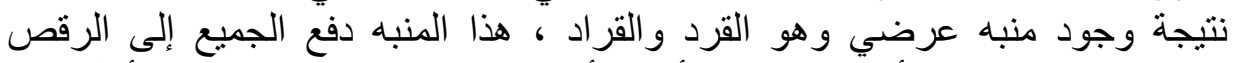

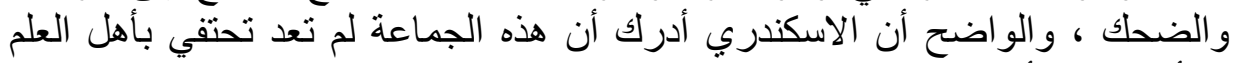

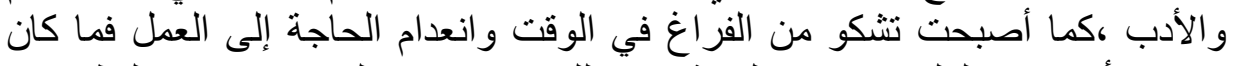

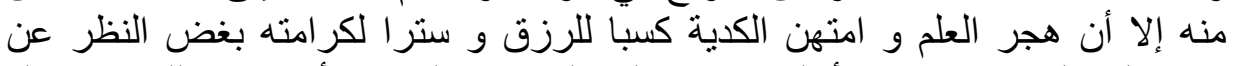

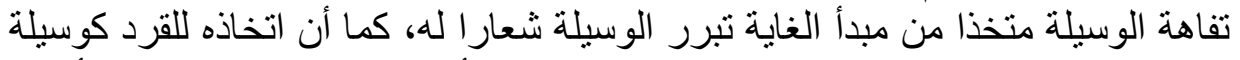

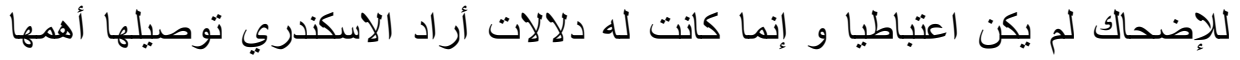

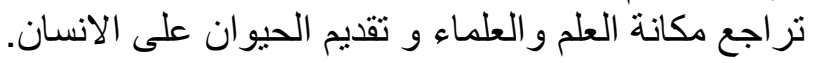

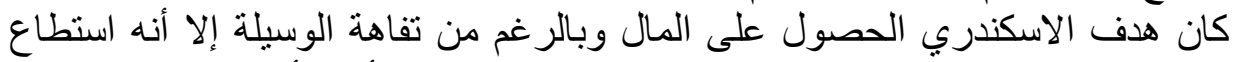

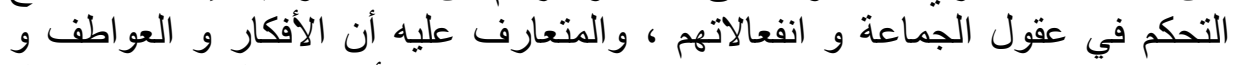

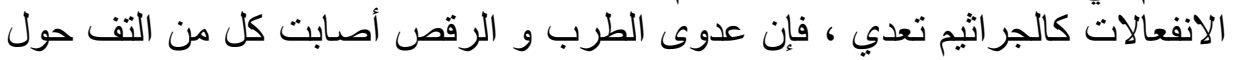

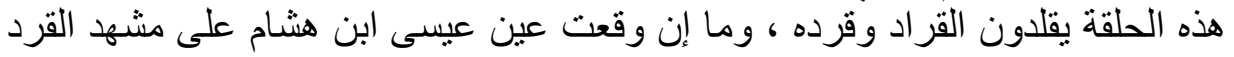

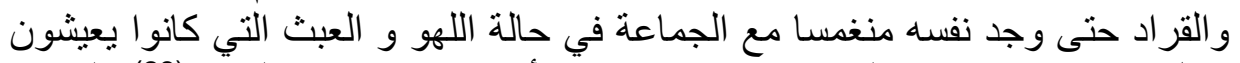

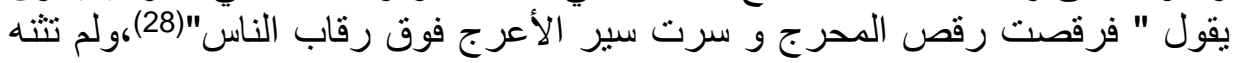

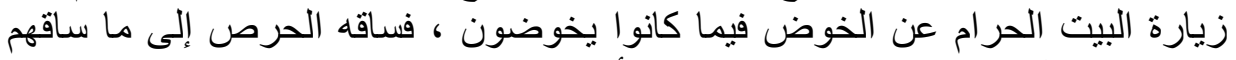

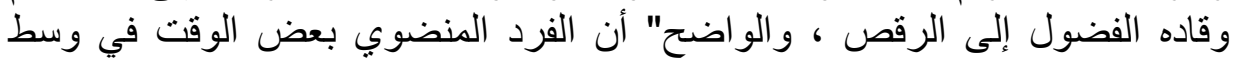

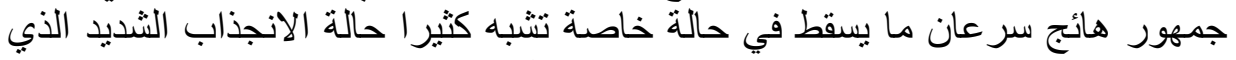

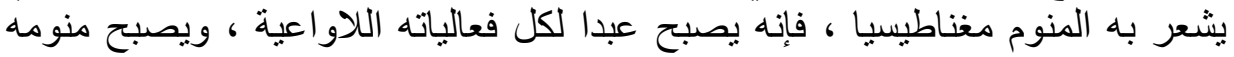

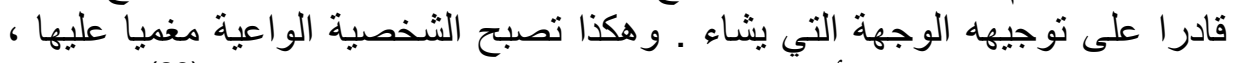

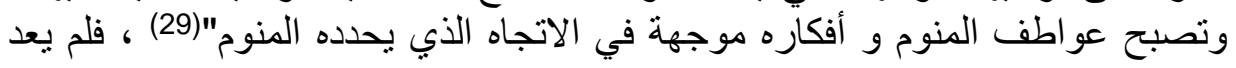


عيسى ابن هشام و كل من كان في الحلقة واعيا بأعماله ، الجميع يرقص وكأنها عدوى

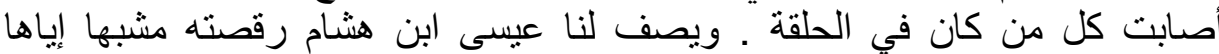

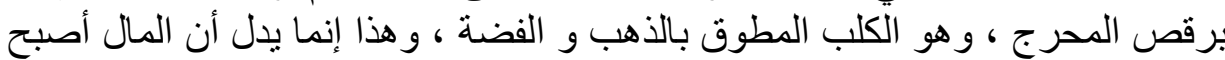

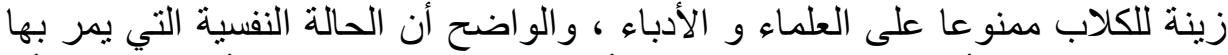

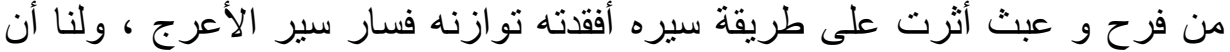

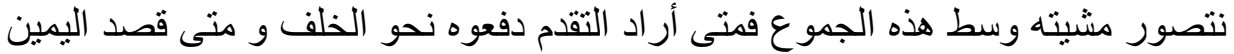

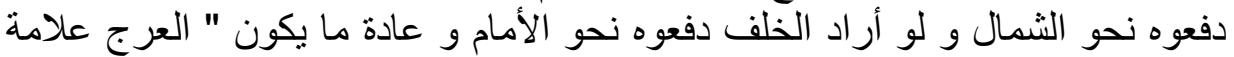

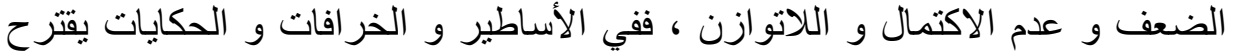

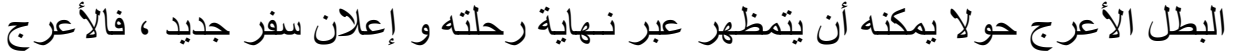

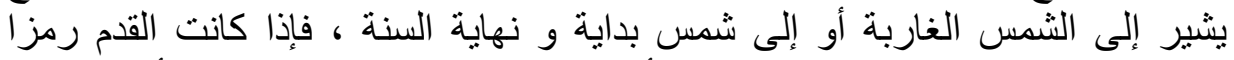

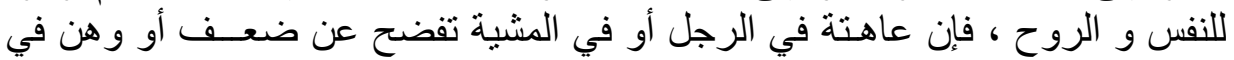
النفس"(30) - (النفن

إن توظيف العرج هنا ليس لكونه عاهة جسدية بقدر ما هو عاهة نفسية نثي بضعف النف النفا

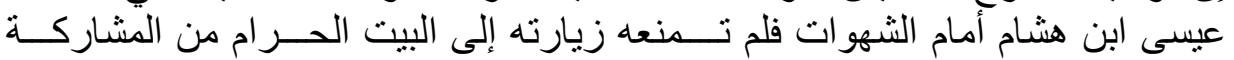

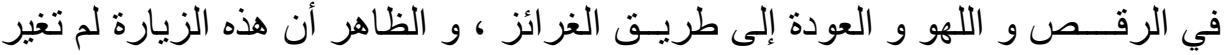

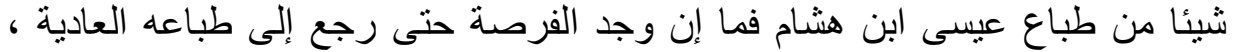

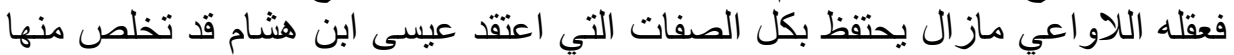

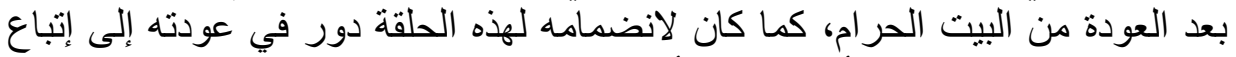

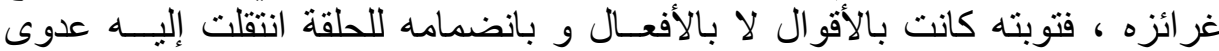

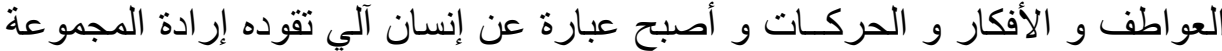

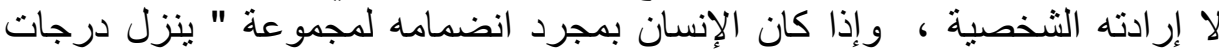
عديدة في سلم الحضارة ، فهو عندما يكون فردا معزو لا ربما يكون إنسانا منقفا متعقلا

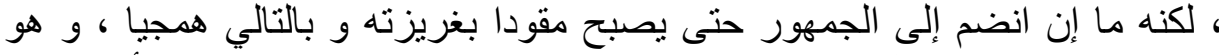

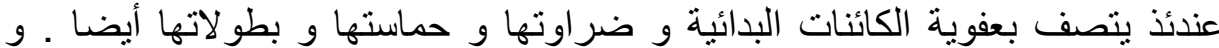

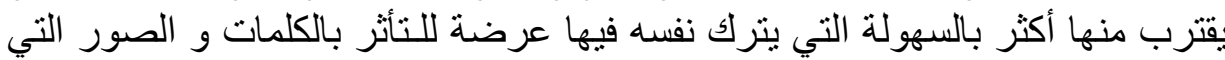

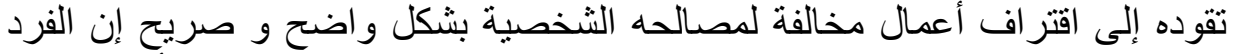

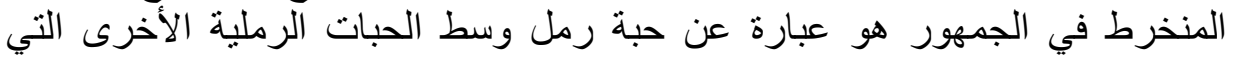

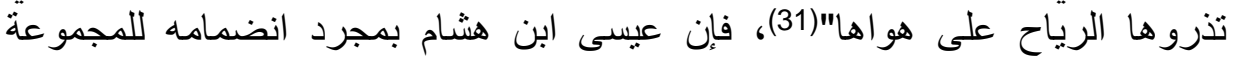

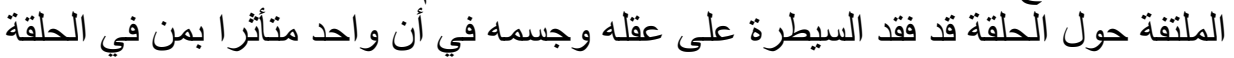

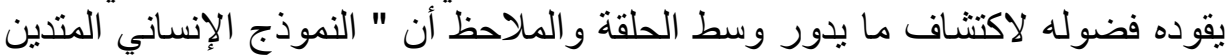

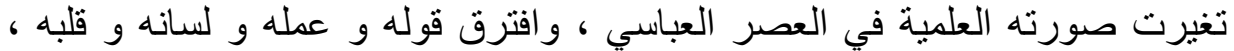

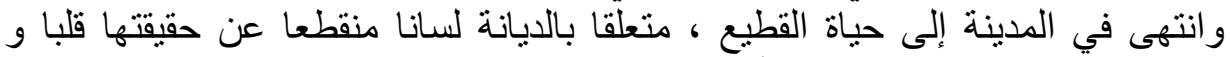

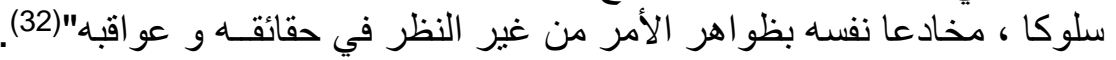

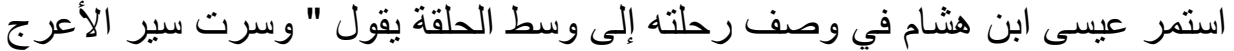

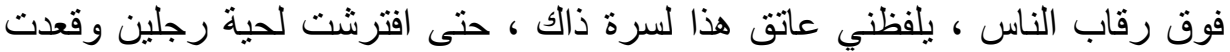

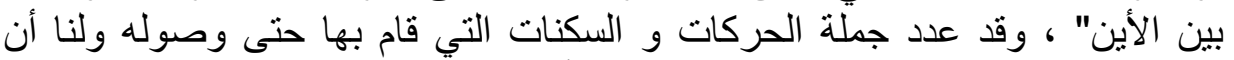

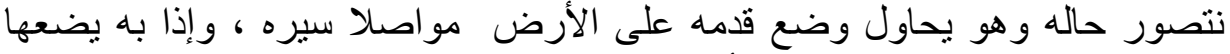

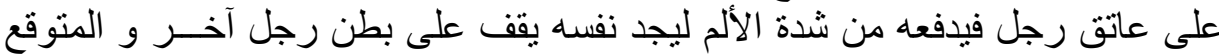

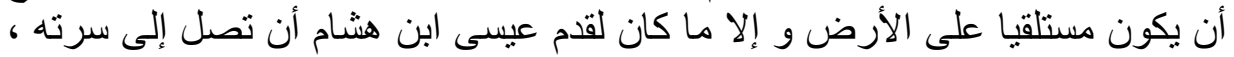

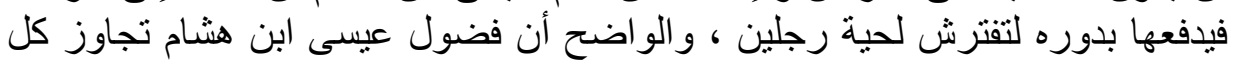

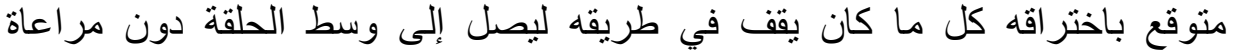

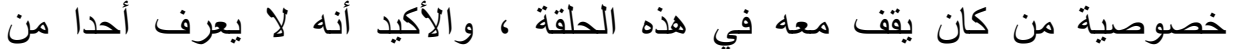

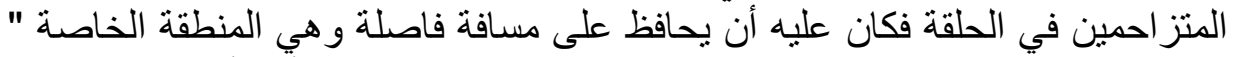

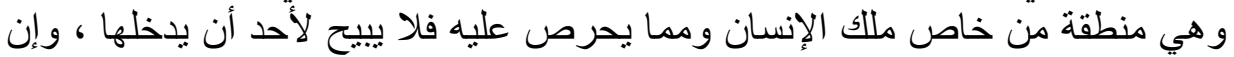

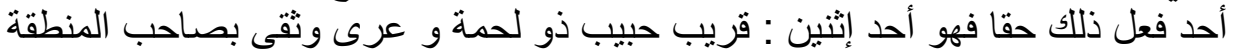




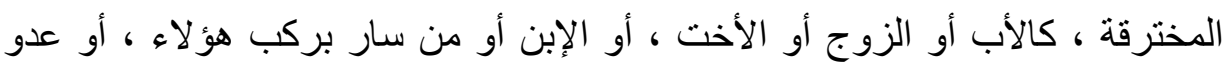

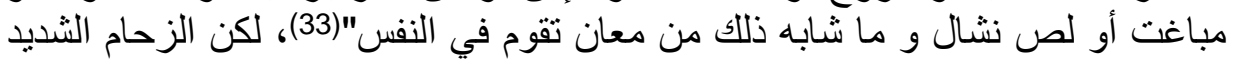

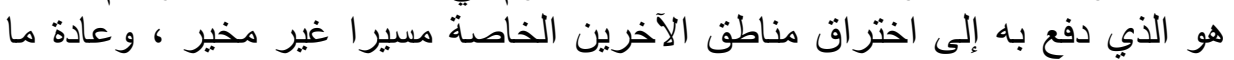

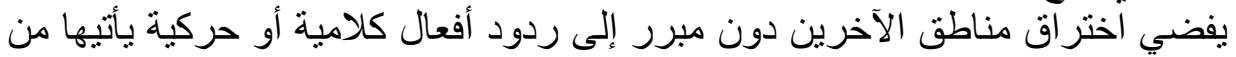

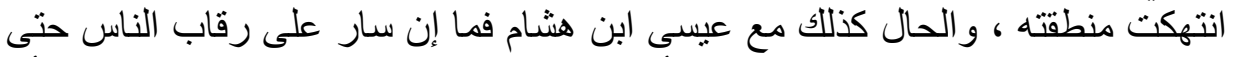

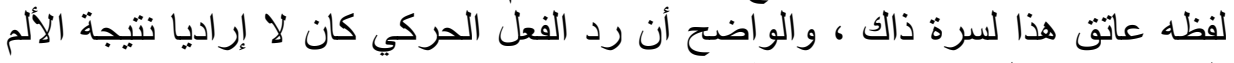

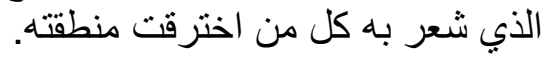

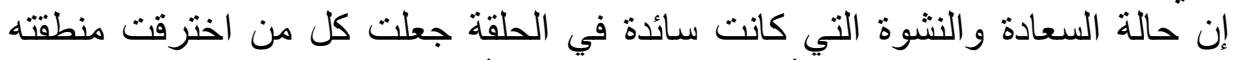

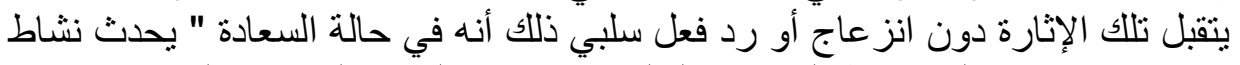

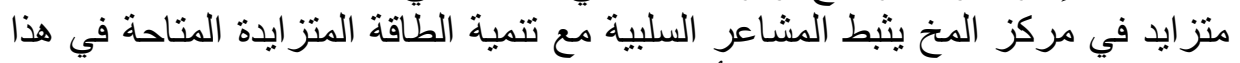

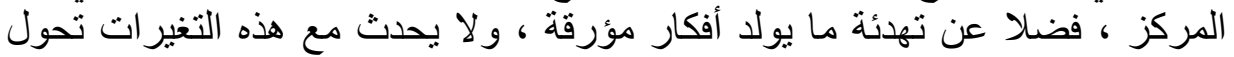

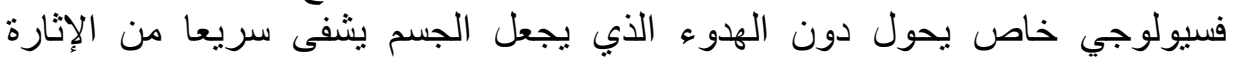

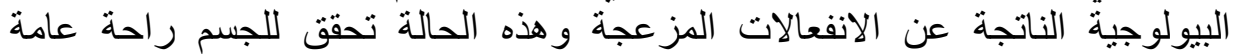

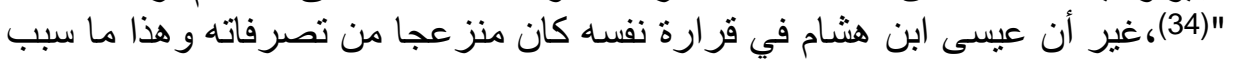

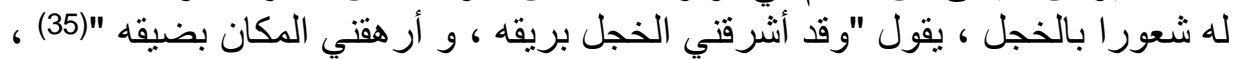

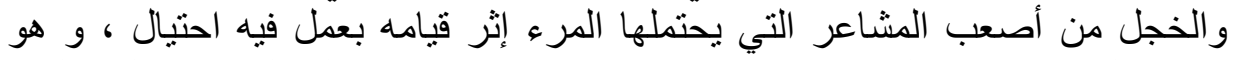

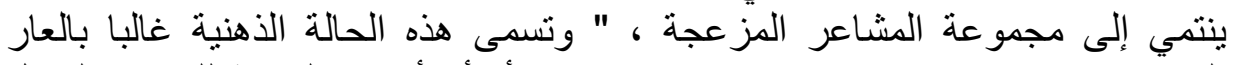

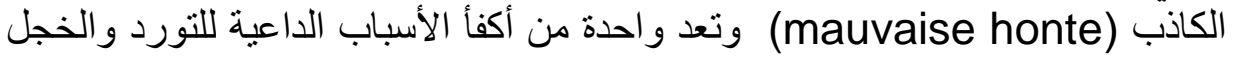

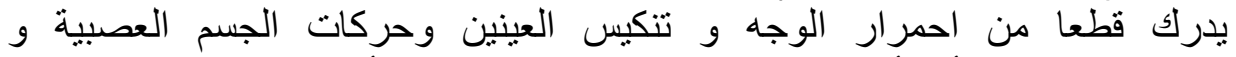

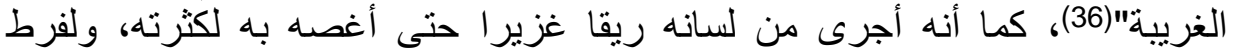

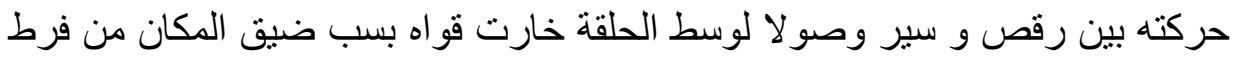

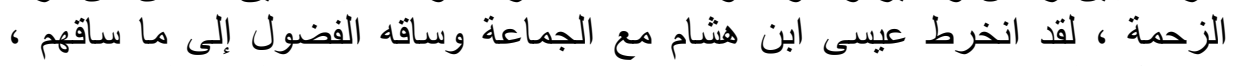

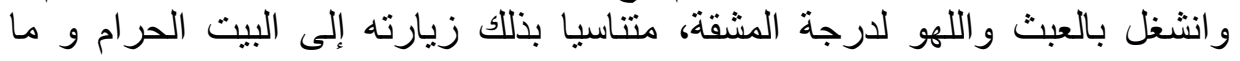

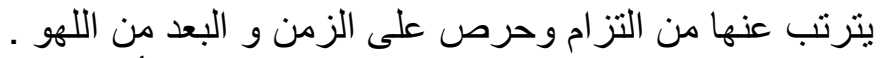

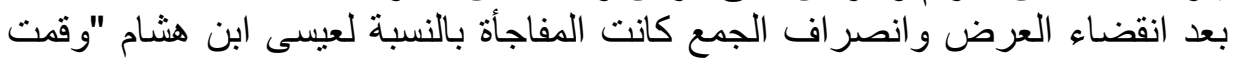

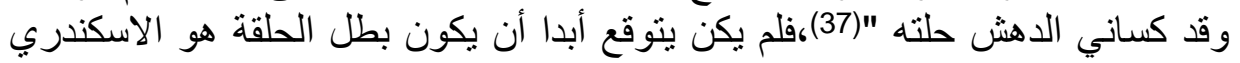

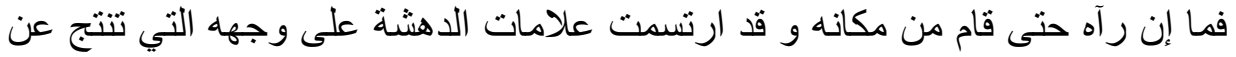

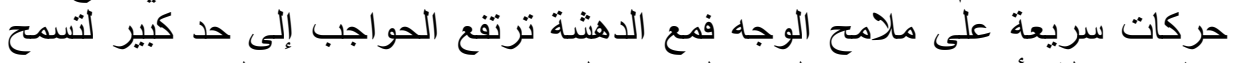

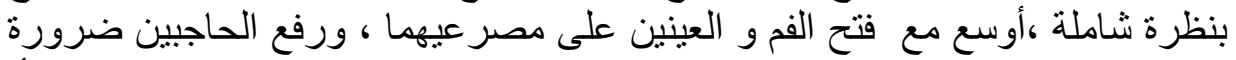

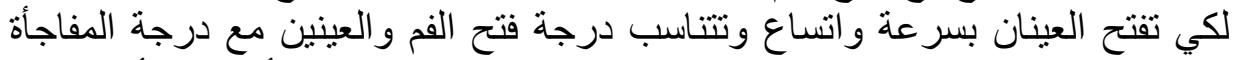

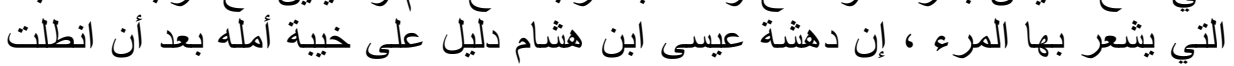

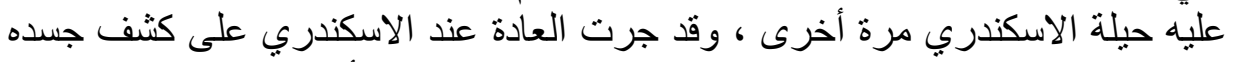

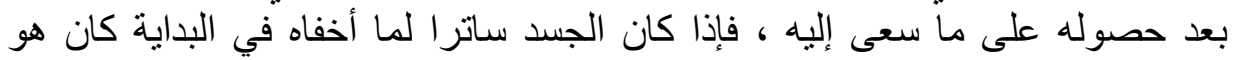

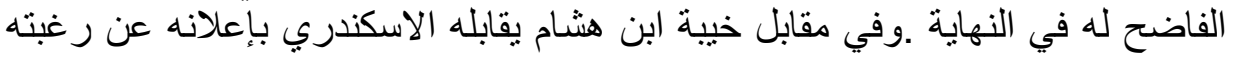
في تحقيق غايته بغض النظر عن تفاهة الوسيلة

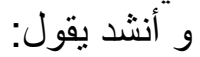

$$
\text { فاعتب على صرف الليالي }
$$

محملا المسؤولية للأيام و الليالي و تقلبهها ، و وذذا ما دفعه ليسلك أقصر السبل لجمع المال في ذلك الزمان 
من خلال هذه الدر اسة يمكن أن نخلص إلى النتائج التالية:

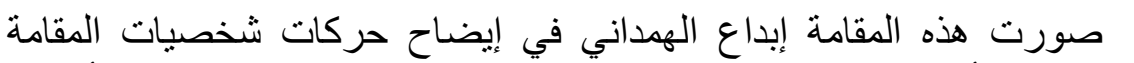

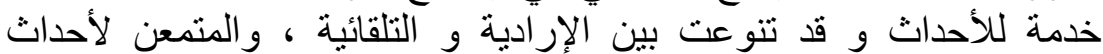

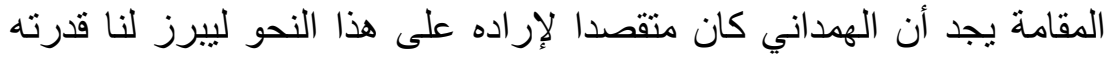

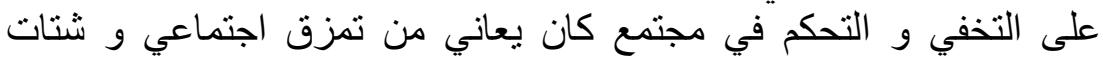

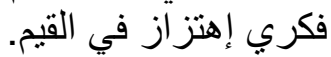

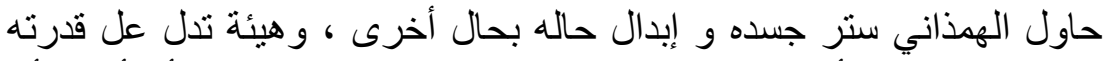

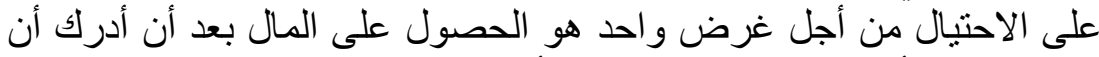

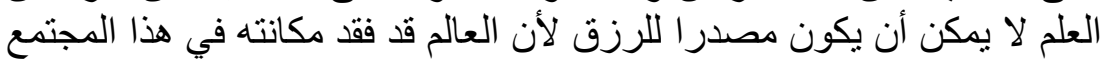

كثف لغة جسد كل من كان في الحلقة على الكثير مما تخفيه نفوسهم ، فظاهر

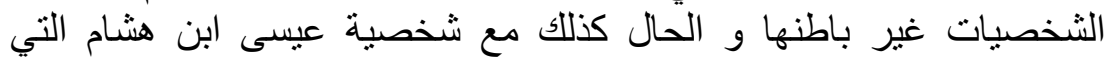

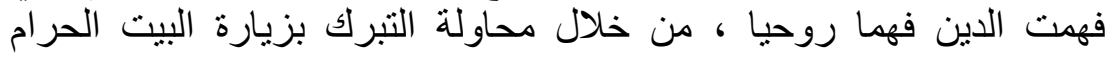

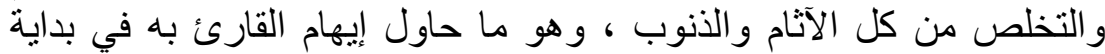

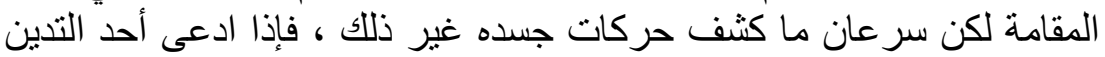

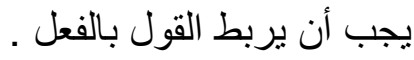

لم يكتف الاسكندري بجسده كوسيلة للاحتال على كل من بل كان في في الحلقة

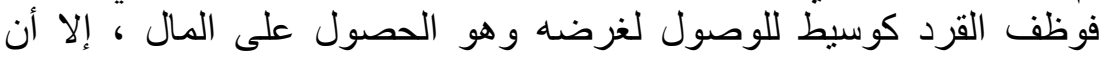

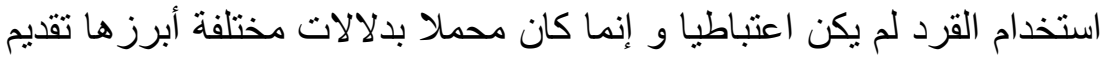

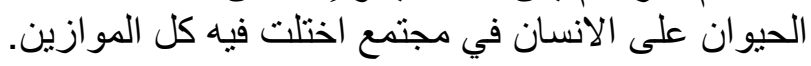

(1)-محمد محمد داود، جسد الإنسان والتعبيرات اللغوية (در اسة دلالية و معجم) دار المجار

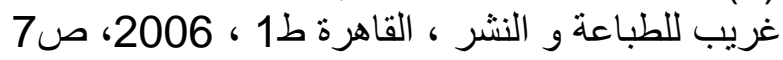
(2)-المرجع نفساه ، الصفحة نفئها.

(3)-بني يونس محمد محمود ،سيكولوجيا الدافعية والانفعالات ط1، دار ميسرة

(5)-الأزهر الزناد ، اللغة والجسد، مركز النشر التعبرات اللغرية الجامعي ، تونس ، 2017،

(6)-محمد الأمين موسى أحمد ، الاتصال غير اللفظي في القرآن الكريم ، دار الثقافة

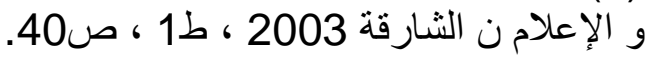

(7)- المرجع نفسه ، الصفحة نفسها.

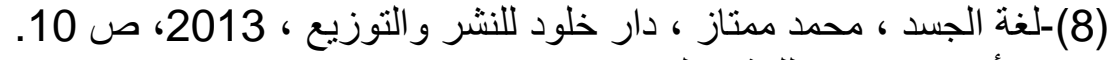

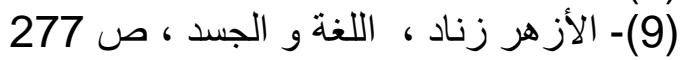

(10)- المرجع السابق الصفحة نفسها.

278 (11)

(12)-مهدي أسعد عرعار ، البيان بلا لسان، دار الكتب العلمية ، لبنان ،ص38.

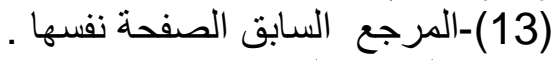

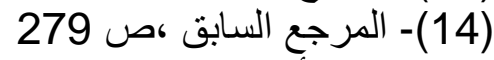

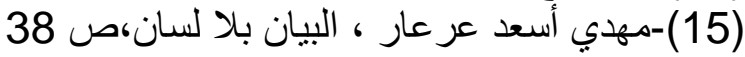

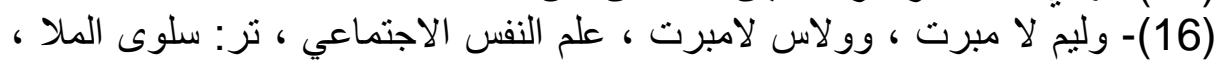




$$
\begin{aligned}
& \text { دار الثروق ، بيروت ، }
\end{aligned}
$$

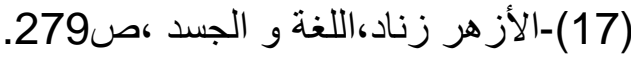

$$
\begin{aligned}
& \text { (18)-المرجع نفسه } \\
& \text { (19)-المرجع نفسه نفهـ }
\end{aligned}
$$

(20)-كريم زكي حسام الدين ، الإشارات الجسمية" در اسة لغوية لظاهرة استعمال

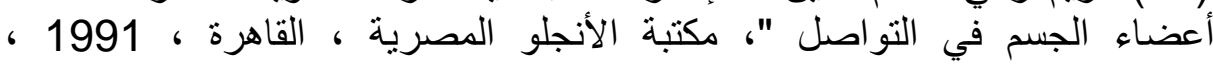

(22)-مهدي أسعد عرعار، البيان بلا لسان نقلا عن نتالي باكو ،لغة الحركات ،

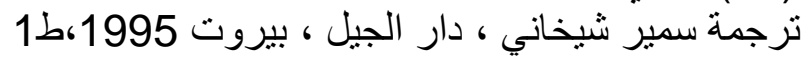
(23)

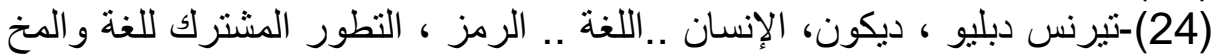

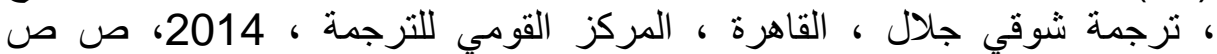

(27)-ثيرنس دبليو ، ديكون : الانسان اللغة الرمز، التطور المشترك للغة والمخ ،

(29)- غوستاف لو بون ، سيكلوجيا الجماهير ، تر : هاثم صالح ، بيروت ـ لندن ، الطبعة 7 ، 2016 (30)

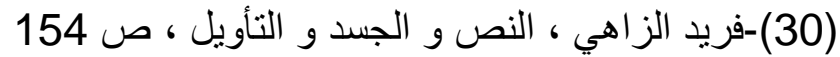

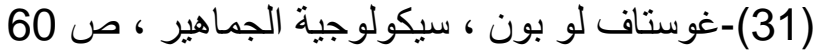

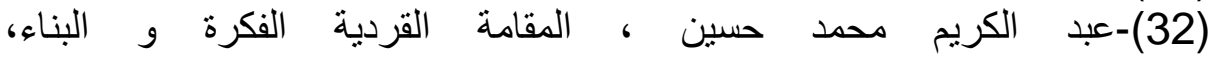
،/?=21197102 www.startimes.com

(33)-المرجع السابق ، ص 63 (34)

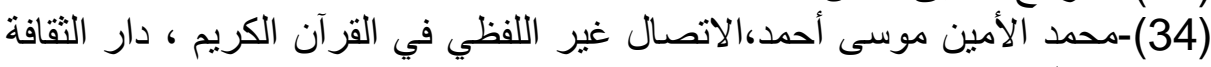

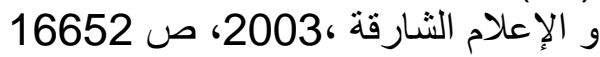

(35)

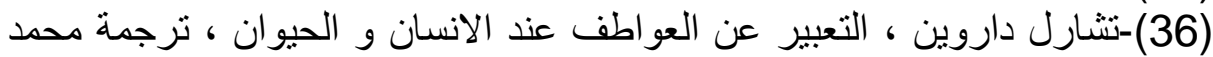
عبد الستار شيخلي ، مركز دراسات الوحدة العربن العربية ، ط1، بيروت ،جوان 2010، 